\title{
Hypersecretion of Proinsulin in Thyrotoxicosis
}

\author{
L. Sestoft and L. G. Heding \\ Hvidøre Hospital, Klampenborg, Copenhagen, County Hospital, Herlev, and Novo Research Institute, Bagsværd, Denmark
}

Summary. The plasma insulin, C-peptide and proinsulin concentrations were investigated in thyrotoxic patients and in normal controls after an overnight fast, during a $36 \mathrm{~h}$ fasting period, an intravenous glucose tolerance test and an oral glucose tolerance test. The main finding was a significantly raised concentration of proinsulin in plasma of patients with thyrotoxicosis. After an overnight fast the plasma proinsulin was $0.048 \pm 0.005 \mathrm{pmol} / \mathrm{ml}$ in 15 thyrotoxic patients compared with $0.023 \pm 0.012 \mathrm{pmol} / \mathrm{ml}$ in 15 euthyroid controls. A twofold rise of plasma proinsulin concentration was also found in thyrotoxic patients during a prolonged fast, and during intravenous and oral glucose tolerance tests. The immunoreactivity of proinsulin in the insulin radioimmunoassay gave rise to slightly elevated concentrations of immunoreactive insulin in thyrotoxic patients in all the conditions investigated. When insulin values were corrected for proinsulin crossreactivity, they were similar in euthyroid controls and thyrotoxic patients. The concentration of plasma Cpeptide was not significantly altered in thyrotoxic patients during intravenous and oral glucose tolerance tests.

Key words: Thyrotoxicosis, insulin secretion, proinsulin, C-peptide, insulin immunoreactivity.

\section{Introduction}

The effect of thyrotoxicosis on insulin secretion in man has not been completely clarified. In thyrotoxic patients insulin determined radioimmunochemically may be either normal or increased both in the fasting state and after a glucose challenge [1-4], while glucose tolerance is impaired [1-3]. On the other hand, it has been shown experimentally that insulin secretion is decreased in hyperthyroid animals [5-7], and the pancreatic insulin content from such animals is decreased [8]. All studies to date have used radioimmunoassays for the measurement of insulin. Such assays measure not only insulin but also proinsulin, and the contribution of the latter moiety is variable. In order to see whether proinsulin contributes significantly to the immunoreactive insulin concentrations in thyrotoxic patients, we have measured proinsulin, insulin, and C-peptide in a group of thyrotoxic patients following short and prolonged fasting and during glucose tolerance tests.

\section{Subjects and Methods}

\section{Subjects}

The clinical details of the patients and controls are given in Table 1 . The study included three different patient groups with thyrotoxicosis which underwent either A) an overnight fast, B) a $36 \mathrm{~h}$ fast or C) oral and IV glucose tolerance tests. No subject appeared in more than one group. None of the subjects were taking drugs apart from sedatives of the benzodiazepine group, and none suffered from any other major disease. Before the study informed consent was obtained from all patients.

Each group had a separate group of euthyroid controls, which for groups $\mathrm{B}$ and $\mathrm{C}$ were selected to match the patient group with respect to age and sex. Group A were consecutive patients appearing in the outpatient clinic, and the control group consisted of outpatients with minor ilnesses, mostly varicose veins.

\section{Protocols}

Plasma insulin, C-peptide, and proinsulin concentrations were determined in all patients and controls in the three study groups (Table 1 ). The prolonged fasting period was preceded by a light meal $(1600 \mathrm{~kJ})$. Blood samples were obtained from an indwelling needle in the antecubital vein every $6 \mathrm{~h}$. During the fasting period smoking was prohibited. An oral glucose tolerance test was performed by giving $1.75 \mathrm{~g}$ glucose $/ \mathrm{kg}$ body weight and blood samples were taken eight times during the following $180 \mathrm{~min}$. An IV glucose tolerance test was performed by giving $0.5 \mathrm{~g}$ glucose $/ \mathrm{kg}$ body weight in a $50 \%(w / v)$ solution IV over a 3 -min period. Five plasma samples were collected over the following $60 \mathrm{~min}$ from an indwelling needle. 
Table 1. Data for thyrotoxic patients and control subjects

\begin{tabular}{|c|c|c|c|c|c|c|c|}
\hline & & $\begin{array}{l}\text { No of } \\
\text { patients }\end{array}$ & $\begin{array}{l}\text { Age } \\
\text { (years) }\end{array}$ & $\begin{array}{l}\text { Deviation } \\
\text { from ideal } \\
\text { body weight } \\
(\%)\end{array}$ & $9 / 0^{7}$ & $\begin{array}{l}\text { L-thyroxine } \\
(\mu \mathrm{g} / 100 \mathrm{ml}) \\
(4.3-10.0)\end{array}$ & $\begin{array}{l}\text { Triiodothyronine } \\
(\mathrm{ng} / 100 \mathrm{ml}) \\
(106-182)\end{array}$ \\
\hline \multirow{2}{*}{ Group A } & $\begin{array}{l}\text { Overnight fast } \\
\text { (controls) }\end{array}$ & 5 & $39 \pm 6$ & $-9.7 \pm 13$ & $4 / 1$ & $6.7-0,9$ & $147-5$ \\
\hline & $\begin{array}{l}\text { Overnight fast } \\
\text { (thyrotoxic) }\end{array}$ & 6 & $62 \pm 4$ & $-9.9 \pm 7.9$ & $6 / 0$ & $12.1 \pm 2.0$ & $309 \pm 48$ \\
\hline \multirow{2}{*}{ Group B } & $\begin{array}{l}\text { Prolonged fast } \\
\text { (controls) }\end{array}$ & 4 & $36 \pm 6$ & $-7 \pm 10$ & $3 / 1$ & $6.7 \pm 1.8$ & $114 \pm 20$ \\
\hline & $\begin{array}{l}\text { Prolonged fast } \\
\text { (thyrotoxic) }\end{array}$ & 4 & $35 \pm 5$ & $-9 \pm 11$ & $3 / 1$ & $19.4 \pm 5.4$ & $412 \pm 292$ \\
\hline \multirow{2}{*}{ Group C } & $\begin{array}{l}\text { Glucose tolerance } \\
\text { tests (controls) }\end{array}$ & 6 & $43 \pm 18$ & $-3.8 \pm 12$ & $6 / 0$ & $6.2 \pm 1.2$ & $121 \pm 17$ \\
\hline & $\begin{array}{l}\text { Glucose tolerance } \\
\text { tests (thyrotoxic) }\end{array}$ & 5 & $46 \pm 16$ & $-1.2 \pm 11$ & $5 / 0$ & $14.8 \pm 4.0$ & $432 \pm 199$ \\
\hline
\end{tabular}

Results expressed as mean \pm SEM (Normal range for thyroid hormones given in parentheses)
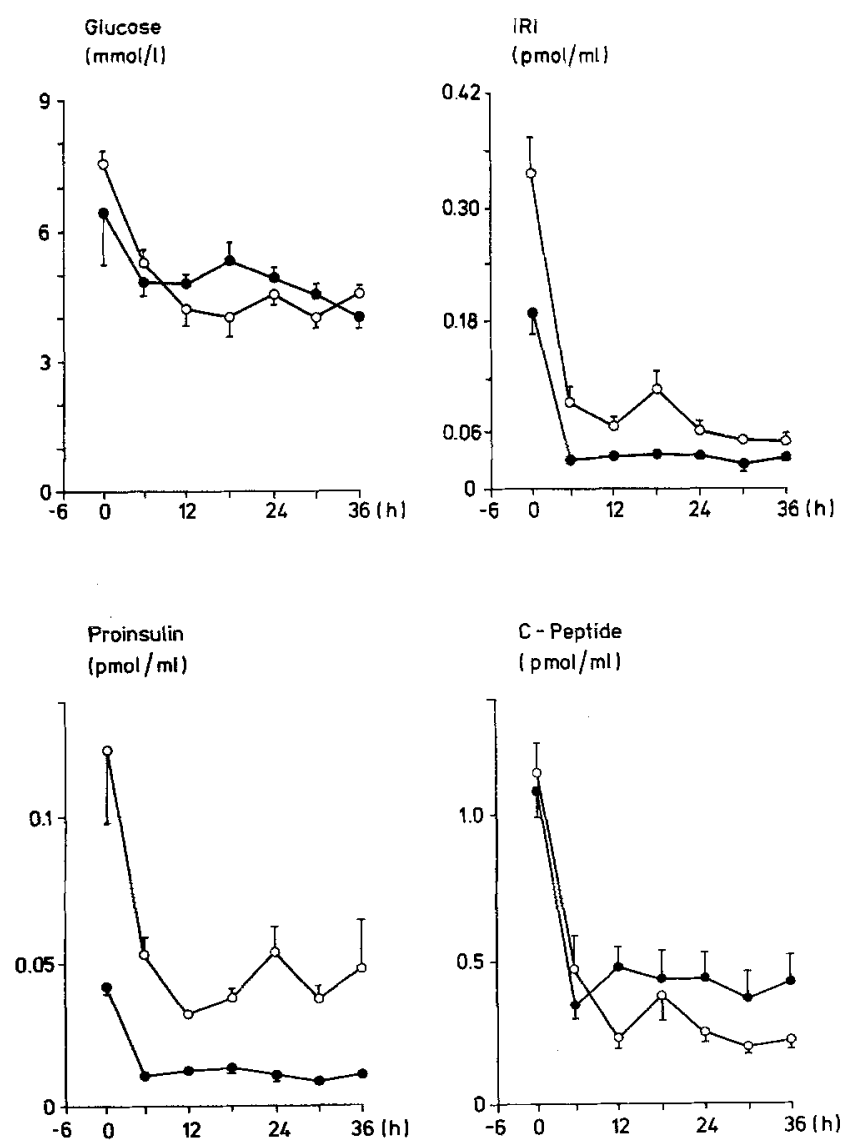

Fig. 1. Mean changes in blood glucose, plasma IRI, proinsulin and C-peptide concentrations in four euthyroid control subjects (๑) and four thyrotoxic patients (O) during a $36 \mathrm{~h}$ fasting period following a light meal. Significant differences were found at 6 and $12 \mathrm{~h}$ for proinsulin $(p<0.05)$

\section{Chemical Methods}

Plasma glucose was determined by the glucose oxidase method (Boehringer Mannheim, Germany). Serum thyroxine and triiodothyronine concentrations were determined radioimmunochemically $[9,10]$. Plasma immunoreactivity of insulin (IRI) was determined as described previously [11]. Plasma C-peptide was determined after removal of proinsulin by Sepharose-bound insulin antibodies (S-AIS) by a radioimmunoassay using antiserum M 1181, synthetic ${ }^{125}$ I-Tyr-C-peptide and synthetic C-peptide [12]. Plasma proinsulin was determined after binding to S-AIS, using human proinsulin $(0.005-0.5 \mathrm{pmol} / \mathrm{ml}$; donation from Professor A. Rubenstein, Chicago) as a standard and synthetic ${ }^{125} \mathrm{I}$ Tyr-C-peptide as tracer [13]. The antiserum was either anti-crude proinsulin serum $\mathrm{M} 1181$ or anti-synthetic C-peptide serum. M 1219.

The sensitivity expressed as SD within assay was for IRI 0.0025 , for proinsulin 0.001 , and for C-peptide $0.004 \mathrm{pmol} / \mathrm{ml}$. The detection limit was for IRI 0.0062 , for proinsulin 0.002 , and for C-peptide $0.01 \mathrm{pmol} / \mathrm{ml}$.

The insulin concentration was calculated as the IRI concentration with subtraction for proinsulin crossreactivity, which in our assay amounts to $67 \%$ of the proinsulin concentration [14].

Values are given as mean \pm SEM. Differences in the mean values of individual points and differences in the areas under the concentration curves during the tolerance tests were evaluated by Student's unpaired t-test.

\section{Results}

\section{Plasma Hormone Concentrations After an Overnight Fast}

The thyrotoxic patients in group A had a significantly elevated plasma proinsulin concentration $(0.049 \pm$ $0.005 \mathrm{pmol} / \mathrm{ml})(n=6)$ compared with euthyroid 
controls $(0.027 \pm 0.010 \mathrm{pmol} / \mathrm{ml}(n=5, p<0.05)$. The concentrations of insulin and C-peptide did not differ in the patients and controls.

Plasma concentrations of the peptides measured after $12 \mathrm{~h}$ fast in all 15 controls and in the 15 thyrotoxic patients were also analysed. The plasma IRI concentration was $0.042 \pm 0.017 \mathrm{pmol} / \mathrm{ml}$ in euthyroid controls and significantly higher in thyrotoxic patients $(0.064 \pm 0.028 \mathrm{pmol} / 1, p<0.02)$. In contrast the plasma C-peptide concentration was identical in the two groups $(0.57 \pm 0.06 \mathrm{pmol} / \mathrm{ml}$ in the controls and $0.57 \pm 0.01 \mathrm{pmol} / \mathrm{ml}$ in the thyrotoxic patients). Again the most important difference was in the plasma proinsulin concentration, which was $0.023 \pm 0.012 \mathrm{pmol} / \mathrm{ml}$ in the control subjects and $0.048 \pm 0.006 \mathrm{pmol} / \mathrm{ml}$ in the thyrotoxic patients $(p$ $<0.001$ ).

If, however, the IRI concentration is corrected for crossreacting proinsulin in the assay, the insulin concentration in the normal controls was $0.026 \pm$ $0.011 \mathrm{pmol} / \mathrm{ml}$, which is similar to $0.033 \pm 0.010$ $\mathrm{pmol} / \mathrm{ml}$ found in the thyrotoxic patients. Moreover it can be concluded that on a molar basis insulin and proinsulin are circulating in equal concentrations in fasting euthyroid subjects $(0.026$ and $0.027 \mathrm{pmol} / \mathrm{ml}$, respectively), whereas in thyrotoxic patients the proinsulin concentration is $50 \%$ higher than insulin concentration after an overnight fast (0.049 versus $0.033 \mathrm{pmol} / \mathrm{ml}$, respectively).

\section{Plasma Hormone Concentrations During a Prolonged Fast}

The concentrations of glucose, insulin, C-peptide and proinsulin during a $36-\mathrm{h}$ fasting period are shown in Fig. 1. Concentrations of IRI, proinsulin, and C-peptide achieved a basal state $6 \mathrm{~h}$ after a light breakfast in the four normal controls, but not in the thyrotoxic patients. The concentrations of plasma insulin and Cpeptide were not significantly different in the two groups. The general level of the proinsulin concentration was two times higher in the thyrotoxic group than in the controls, with significantly different mean values at 6 and $12 \mathrm{~h}$ after the light meal.

\section{Plasma Hormone Concentrations During an Oral Glucose Tolerance Test (Fig. 2)}

After an oral glucose tolerance test there were no significant differences between the insulin (and Cpeptide) values at individual points or between the areas under the insulin (or C-peptide) curve in the normal and the thyrotoxic subjects. However, the
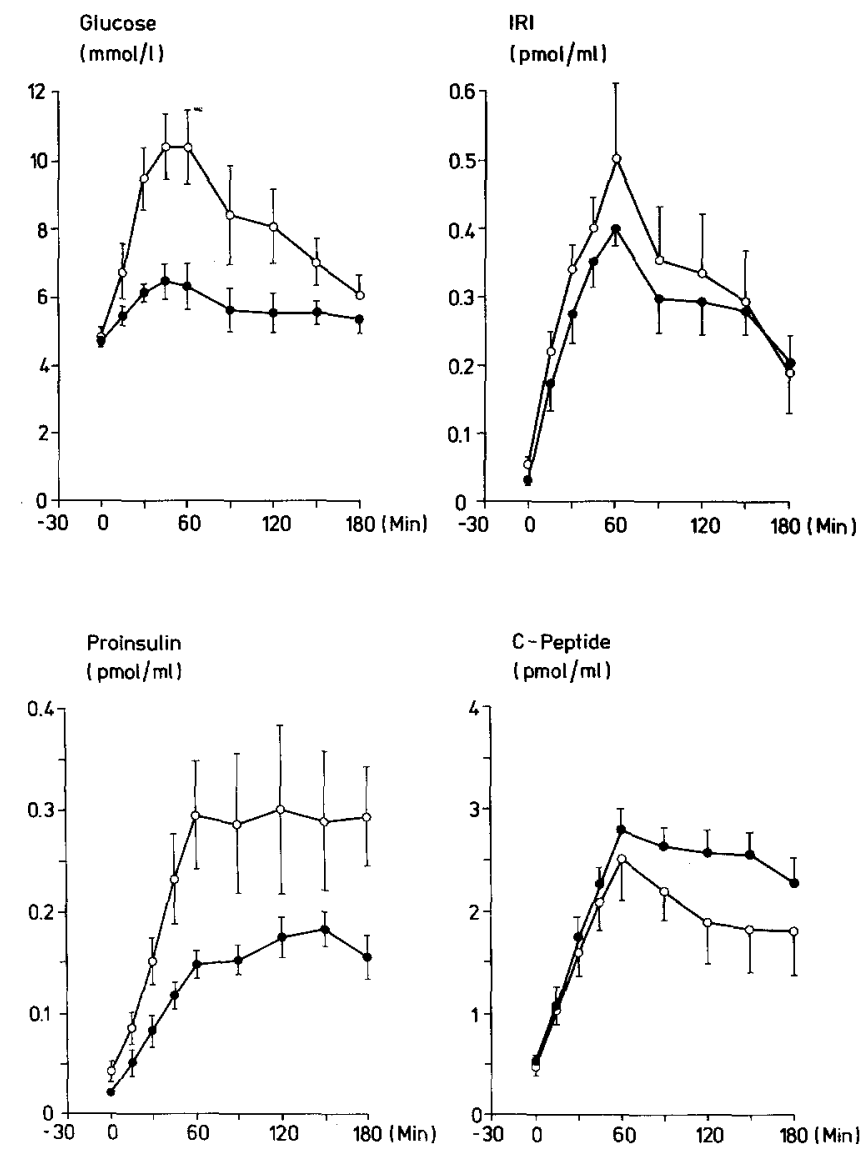

Fig. 2. Mean changes in blood glucose, plasma IRI, proinsulin and C-peptide concentrations in six euthyroid control subjects $(\bullet)$ and five thyrotoxic patients $(0)$ during an oral glucose tolerance test. Significant differences were found for proinsulin at $30,45,60$ and $180 \mathrm{~min}(p<0.05)$ and for glucose at 30,45 and $60 \mathrm{~min}(p<$ $0.05)$

subjects with thyrotoxicosis showed a marked difference in the blood glucose levels.

The pattern of secretion of proinsulin was very similar to that of $\mathrm{C}$-peptide with an approximately linear increase in the plasma concentration up to $60 \mathrm{~min}$ after the glucose load. However, the proinsulin concentration in the thyrotoxic group was twofold greater than in the control group, and significant differences were attained at the individual points 30,45 , 60 , and $180 \mathrm{~min}$.

\section{Plasma Hormone Concentrations During a IV Glucose Tolerance Test (Fig. 3)}

As with the oral glucose tolerance test, these subjects showed no significant differences with regard to IRI and C-peptide concentrations between the groups 

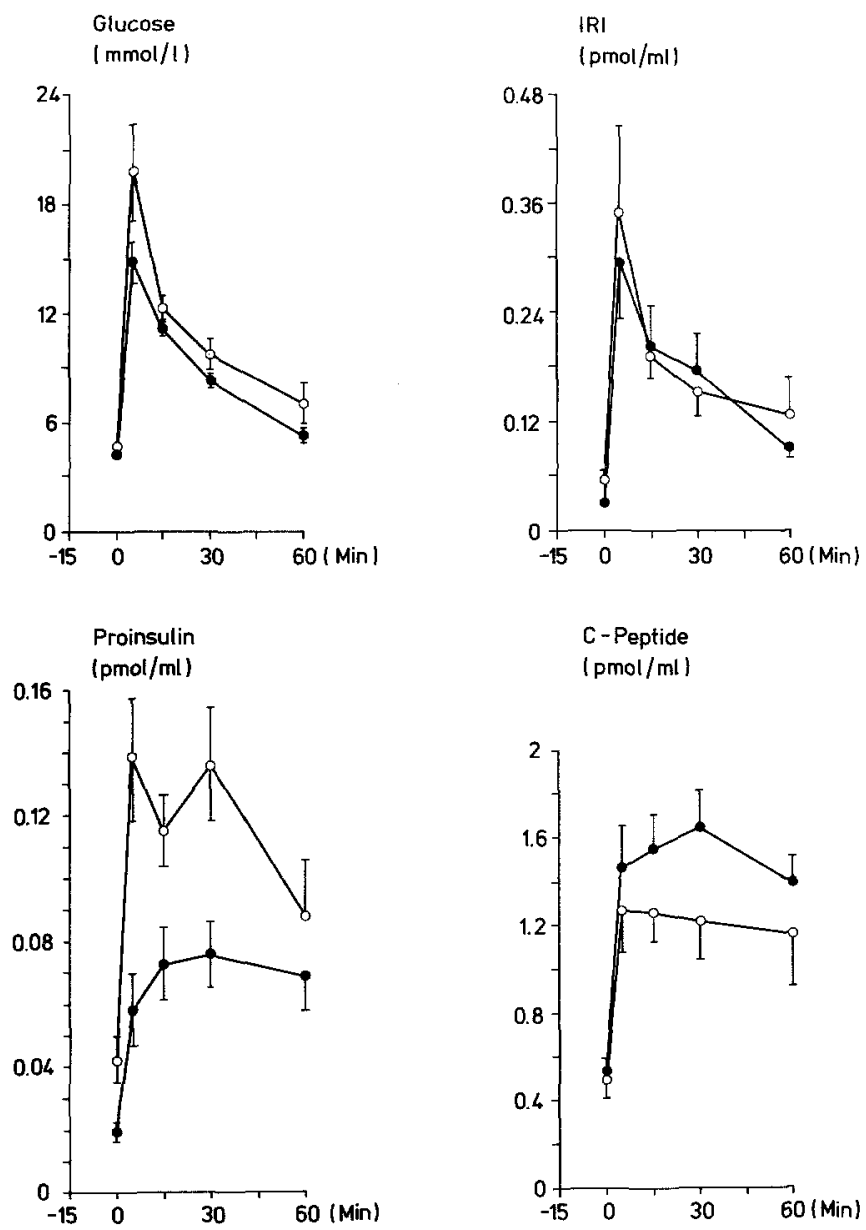

Fig. 3. Mean changes in the blood glucose, plasma IRI, proinsulin and $\mathrm{C}$-peptide concentrations in six euthyroid control subjects $(\bullet)$ and five thyrotoxic patients $(0)$ (the same subjects as in Fig. 2) during a glucose tolerance test. Significant differences were found for proinsulin at all sampling points $(p<0.05)$ except 60 min

during an IV glucose tolerance test. However, the plasma proinsulin concentration before and during a glucose tolerance test was increased by $100 \%$ in the thyrotoxic patients compared with the normal controls. Significant differences were attained at all individual sample points except $60 \mathrm{~min}$.

In one patient an oral glucose tolerance test and an IV glucose tolerance test were performed before and after treatment of the thyrotoxicosis. Following therapy with propylthiouracil, the fasting proinsulin concentration decreased from 0.046 to $0.015 \mathrm{pmol} /$ $\mathrm{ml}$. During the oral glucose tolerance test, the peak value decreased from 0.500 (at $60 \mathrm{~min}$ ) to 0.140 $\mathrm{pmol} / \mathrm{ml}$ (at $150 \mathrm{~min}$ ) following treatment. The peak values during the IV glucose tolerance test were 0.180 (at $5 \mathrm{~min}$ ) and $0.060 \mathrm{pmol} / \mathrm{ml}$ (at $60 \mathrm{~min}$ ) before and after treatment respectively.

\section{Discussion}

The main finding in this study is that thyrotoxicosis is accompanied by significant elevations in the plasma concentration of circulating proinsulin. This phenomenon in thyrotoxic patients was observed in the fasting state and also during both oral and IV glucose tolerance tests. Thus, in hyperthyroidism it could be argued that the pancreatic B cell has an increased capacity to secrete proinsulin compared with the euthyroid state, and proinsulin is circulating in high concentrations because of the relatively slow rate of proinsulin removal $[15,16]$. In contrast to insulin independent diabetes, where the fasting proinsulin concentration is also increased [17], the concentration of proinsulin in thyrotoxicosis is frequently so high that it is in the range which is considered characteristic of patients with insulinomas $[14,18]$.

The phenomenon of hyperinsulinaemia may be far more common than generally appreciated since proinsulin crossreactivity with insulin has been usually ignored in studies of various conditions in which insulin responses to glucose or other stimuli have been determined.

The circulating "true insulin" concentration is the same in thyrotoxic patients and in controls. However, as judged from the C-peptide response to glucose, the capacity for insulin secretion is unchanged or somewhat decreased in thyrotoxicosis. The latter possibility is in line with experimental studies which show a decreased response of insulin secretion to glucose in hyperthyroidism [5-7, 19]. In such animals the pancreatic islet mass is also decreased [8].

A combination of decreased insulin secretion and normal circulating insulin concentrations may be explained by a decreased rate of degradation of insulin in hyperthyroidism, but there is no direct evidence for this in man $[20,21]$. Proinsulin can displace native insulin from the insulin receptor [22, 23], but the affinity of proinsulin for the insulin receptor and its biological effect is only about $2 \%$ of that of insulin $[22,23]$. Therefore, neither decreased insulin degradation nor glucose intolerance in thyrotoxic patients can be understood on the basis of receptor interactions between insulin and proinsulin.

As shown previously [11] glucose tolerance may be impaired in thyrotoxic patients despite a normal level of circulating insulin. During an oral glucose tolerance test and an IV glucose tolerance test the inability of the thyrotoxic liver to accumulate glycogen [24] may play a major role in glucose intolerance. The mechanism behind this phenomenon is unknown, but, again, it seems unlikely that it is due to interference of proinsulin with insulin, since in 
other hyperproinsulinaemic states, such as insulin independent diabetes, the liver content of glycogen is increased after an overnight fast [25].

\section{References}

1. Hales CN, Hyams DE (1964) Plasma concentrations of glucose, non-esterified fatty acid, and insulin during oral glucosetolerance tests in thyrotoxicosis. Lancet 2: 69-71

2. Doar JWH, Stamp TCB, Wynn V, Path FC, Audhya TK (1969) Effects of oral and intravenous glucose loading in thyrotoxicosis. Study of plasma glucose, free fatty acid, plasma insulin and blood pyruvate levels. Diabetes 18: 633-639

3. Andersen OO, Friis Th, Ottesen B (1977) Glucose tolerance and insulin secretion in hyperthyroidism. Acta Endocrinol (Copenh) 84: 576-587

4. Wajchenberg BL, Cesar FP, Leme CE, Souza IT, Pieroni PR, Mattar E (1978) Carbohydrate metabolism in thyrotoxicosis: Studies on insulin secretion before and after remission from the hyperthyroid state. Horm Metab Res 10, 294-299

5. Malaisse WJ, Malaisse-Lagae F, McCraw EF (1967) Effects of thyroid function upon insulin secretion. Diabetes 16: 643-646

6. Imura $\mathrm{H}$, Seino $\mathrm{Y}$, Ikeda $\mathrm{M}$, Taminato $\mathrm{T}$, Miyamoto $\mathrm{Y}$, Goto $Y$ (1976) Impaired plasma insulin response to arginine in hyperthyroidism. Diabetes 25: 961-968

7. Lenzen S (1978) Dose-response studies on the inhibitory effect of thyroid hormones on insulin secretion in the rat. Metabolism 27: 81-88

8. Lenzen S, Klöppel $G$ (1978) Insulin secretion and the morphological and metabolic characteristics of pancreatic islets of hyperthyroid ob/ob mice. Endocrinology 103: 1546-1556

9. Siersbæk-Nielsen K (1967) The diagnostic value by thyroid diseases. Acta Med Scand 181: 327-333

10. Skovsted L (1979) Radioimmunoassays of $T_{3}, r-T_{3}$ and $r-T_{2}$ in human serum. Acta Med Scand [Suppl] 624: 19-24

11. Heding LG (1972) Determination of total serum insulin (IRI) in insulin-treated diabetic patients. Diabetologia 8: 260

12. Heding LG (1978) Insulin, C-peptide, and proinsulin in nondiabetics and insulin-treated diabetics. Diabetes 27 [Suppl] 1: 178-183

13. Heding LG (1977) Specific and direct radioimmunoassay for human proinsulin in serum. Diabetologia 13: 467-474
14. Heding LG, Faber O, Kasperska-Czyzykowa T, Sestoft L, Turner R (1979) Radioimmunoassay of proinsulin and hyperproinsulinemic states. In: International Congress Series No. 468. Excerpta Medica, Amsterdam Oxford, p 254-261

15. Sönksen PH, Tompkins CV, Srivastava MC, Nabarro JDN (1973) A comparative study on the metabolism of human insulin and porcine proinsulin in man. Clin Sci 45: 633-654

16. Rubenstein AH, Pottenger LA, Mako M, Getz GS, Steiner DF (1972) The metabolism of proinsulin and insulin by the liver. J Clin Invest 51: 912-921

17. Rainbow SJ, Woodhead JS, Yue DK, Luzio SD, Hales CN (1979) Measurement of human proinsulin by an indirect twosite immunoradiometric assay. Diabetologia 17: 229-234

18. Turner RC, Heding LG (1977) Plasma proinsulin, C-peptide and insulin in diagnostic suppression tests for insulinomas. Diabetologia 13: 571-577

19. Renauld A, Andrade LL, Sverdiik RC, Rodriguez RR (1974) Serum insulin response to glucose infusion in hyperthyroid dogs. Horm Metab Res 6: 400-403

20. Elgee NJ, Williams RH (1955) Effects of thyroid function on insulin- ${ }^{131}$ degradation. Am J Physiol 180: 13-15

21. Wajchenberg BL, Cesar FP, Leme CE, Didio R, Kieffer J (1978) Plasma insulin disappearance curve after intravenous insulin injection in human hyperthyroidism. Clin Endocrinol Metab 8: 233-236

22. Gliemann J, Sørensen HH (1970) Assay of insulin-like activity by the isolated fat cell method. IV. The biological activity of proinsulin. Diabetologia 6: 499-504

23. Gammeltoft S, Kristensen L $\varnothing$, Sestoft L (1978) Insulin receptors in isolated rat hepatocytes. J Biol Chem 253: 8406-8413

24. Mirsky IA, Broh-Khan RH (1936) The effect of experimental hyperthyroidism on carbohydrate metabolism. J Biol Chem 117: 6

25. Sestoft L, Hue L (1980) Gastrointestinal mediator of insulin action. Lancet I: $662-663$

Received: 10 July 1980

and in revised form: 12 March 1981

Dr. L. Sestoft

Hvidøre Hospital

Emiliekildevej 1

DK-2930 Klampenborg, Denmark 